\title{
Social Value In The Novel Hatta: Aku Datang Karena Sejarah By Sergius Sutanto As Teaching Materials In Teaching Literature In Schools
}

\author{
Agus Sulaeman, Goziyah, Ira Anisa Purawinangun, Noermanzah
}

\begin{abstract}
A good novel can teach the value of life and benefits to its readers. One novel that has a life value, especially social values, is the novel Hatta: Aku Datang karena Sejarah by Sergius Sutanto. For this reason, this study aims to describe the social values in Hatta: Aku Datang karena Sejarah by Sergius Sutanto. This research uses a qualitative approach with the content analysis research method. Data collection techniques using documentation techniques that are based on the novel Hatta: Aku Datang Karena Sejarah by Sergius Sutanto. Data analysis techniques with steps: define the unit of analysis, set categories, coding, interpretation, and conclusions. Test the validity of the data using member checks and expert validity. From the results of this study indicate that the social values in the novel Hatta: Aku Datang karena Sejarah by Sergius Sutanto in the form of the value of love, the value of responsibility, the value of harmony in life. The most dominant value of love is found especially about devotion, caring, family, please help, and loyalty. The results of this study are expected to be used as teaching material in schools, especially in strengthening the character of students in Indonesian subjects that contain material about novels so that the social values contained in this novel can be implemented in social life.
\end{abstract}

Index Terms: social value, novel.

\section{INTRODUCTION}

Literary works are the result of creative and imaginative human activities from real life as outlined in written and oral forms so that they contain values and benefits. Literary works are very useful in the development of language teaching because literary works become the main media in delivering students to understand a language (Noermanzah, 2017: 28). Literary works also function as a picture of the life of the results of a person who often presents a life that is colored by the background attitude and beliefs of the author (Aminuddin, 2015 \& Nurgiyantoro, 2013). As one of the literary works, the novel plays an important role in providing a view to addressing life in an imaginative artistic manner and containing moral values that can be taught to students (Hudhana \& Sulaeman, 2019: 32). This is possible because the issues discussed in the novel are questions about humans and humanity. The development of novels in Indonesia is very rapid, as evidenced by the number of new novels published. The novels have a variety of themes and content, including social problems that generally occur in society, including those related to feelings and psychology. Novels as a form of literary work are expected to bring up positive values for the audience so that they are sensitive to problems related to social life and encourage good behavior. Social value is born from the needs of social groups will be a set of measures to control the diverse will of the citizens who are constantly changing in various situations. With that measure, society will know which is good or bad, right or wrong, and may or may not be allowed. According to Martin (2016: 2) \& Gloriani (2013), social values are values related to people's lives.

- $\quad$ Agus Sulaeman, Universitas Muhammadiyah Tangerang, Tangerang City, Indonesia, E-mail: agussulaeman@umt.ac.id

- Goziyah, Universitas Muhammadiyah Tangerang, Tangerang City, Indonesia, E-mail: goziyah@umt.ac.id

- Ira Anisa Purawinangun, Universitas Muhammadiyah Tangerang, Tangerang City, Indonesia, E-mail: iraanisapurawinangun@umt.ac.id

- Noermanzah, Bengkulu University, Bengkulu City, Indonesia, E-mail: noermanzah@unib.ac.id
Social values are values relating to relationships between individuals in society. Social values are also very necessary in the community to revive the spirit of socialization among a community. In this study, researchers chose literary works in the form of novels as research material. The novel used as the object of research is a novel by Sergius Sutanto entitled Hatta: Aku Datang karena Sejarah. Researchers chose this novel because of the interest to discuss the social values reflected in the novel. In this novel, the character named Hatta has a strong motivation in studying and he has a big dream to study up to Egypt. However, destiny said otherwise. Siti Salehah's love and affection had to make that little Hatta's dream buried deeply. Until the end, let time give him inspiration and explanation. The reason for the adoption of social values as research material is because in this novel it elevates the life of a proclaimer, Bung Hatta, which in the novel raises the existence of social values that can be used as teaching material in education circles. Social values are often regarded as things that are related to society because in the community environment we can pay attention to many things, such as daily life, norms of life, morals, and scope (Andrew, 2018; Nugroho, 2018: 29). Zubaedi (2005: 13) \& Tool (2019) expresses social values consisting of several sub-values, including: (1) the value of affection, which is a picture of feelings that humans have. The description of one's affection can be shown through one's attitude to others, which consists of; dedication, caring, kinship, please help, and loyalty; (2) responsibility, i.e. the state of being obliged to bear everything so that it is responsible and obliged to bear, assume, bear all things, or provide answers, and bear the consequences. The nature of responsibility only belongs to some people, because responsibility is a very heavy attitude to take because the consequence is having to be willing to bear everything, which consists of; empathy and the value of belonging; (3) the value of harmony in life, consisting of; tolerance, cooperation, democracy, and justice. This social value has been taught in the lives of Indonesian people since ancient times because social life is inseparable from social activities. This is shown, for example, megalithic culture contains social values such as the value of cooperation and mutual cooperation and religion 
that stand out from the lives of people in South Sulawesi since the 2nd century AD (Hasanuddin, 2016: 191). This social value is also very important because it prepares students to face globalization which is full of challenges and competition. For this reason, this research will try to explain the social values in the novel Hatta: Aku Datang karena Sejarah by Sergius Sutanto. With the hope of being able to see the characteristics of existing social values and provide benefits as a model of teaching materials that can be given to students in understanding the social value of novels.

\section{RESEARCH METHODS}

This research uses a qualitative approach with a content analysis method. According to Sulaeman \& Goziyah (2019: 169), qualitative research data collected in the form of words or quotes. The data in this study are excerpts in which there are social values in the novel Hatta: Aku Datang karena Sejarah by Sergius Sutanto. This novel was published by Qanita, in Bandung in 2018 with the first printing 366 pages thick. The data collection technique in this study is the documentation technique which is Hatta's written document: Hatta: Aku Datang karena Sejarah by Sergius Sutanto. Data analysis techniques in this study were steps, namely establishing the unit of analysis namely social values, establishing categories in the form of types of social values, coding based on the types of social values found and the sequence of events in the novel, interpretation of social values found, and draw conclusions about the characteristics of social values found. Test the validity of the data using a check on the data analysis and the validity of literary teaching experts in interpreting any findings of social value in the novel Hatta: Aku Datang karena Sejarah by Sergius Sutanto.

\section{RESULTS AND DISCUSSION}

\subsection{Results}

The researcher analyzes the social value of Hatta's novel: I Come Because of the History of Sergius Sutanto. Hatta Novel: I Come Because History consists of 51 parts, with each section using subtitles. From section one to section 51 in the novel Hatta: Aku Datang karena Sejarah by Sergius Sutanto is analyzed, researchers obtain sentence quotes as much as 23 quotes. The sentence excerpt consists of a value of affection as many as 10 sentence quotes, the value of responsibility as much as 5 sentence quotation, and the value of life harmony as much as 8 sentence quotation. From the results of data analysis using the content analysis method shows that social values in the novel Hatta: Aku Datang Karena Sejarah by Sergius Sutanto, has three social values, namely: the value of love, the value of responsibility, and the value of harmony in life. The most common element in social value is social value in the value of affection. This value of affection is found because there are values of dedication, caring, kinship, help, and loyalty in Hatta's novel: I Come Because of History. In the in the novel Hatta: Aku Datang Karena Sejarah, the author also presents the life of Bung Hatta in his time.

\subsection{Discussion}

Social values in the novel Hatta: Aku Datang Karena Sejarah by Sergius Sutanto has three social values, namely: the value of affection, the value of responsibility, and the value of harmony in life. This shows that this novel is worth reading material for students in school. From the value of affection, the value of responsibility, and the value of harmony in life is a value that must be taught to students because teaching these values will help teachers in shaping the abilities of students needed in this milineal era, namely creative, collaborative, collaborative, and critical thinking (Karto, et al. 2019: 2718; \& Noermanzah \& Friantary, 2019: 6631). The social values built by Sergius Sutanto use communicative language rhetoric so that it has an effect on readers (Noermanzah, et. Al., 2019: 1794). The social values developed by the authors are values held by a society, regarding what is considered good and what is considered bad by the community. To determine whether something is said to be good or bad, appropriate or inappropriate must go through a process of weighing. Social values provide an overview of the actions that are necessary and important to be carried out by community members and what actions are necessary and not important to do.

The social values found in the novel Hatta: Aku Datang karena Sejarah by Sergius Sutanto are grouped based on the classification of social values based on opinion Zubaedi (2005: 13) \& Tool (2019), namely:

\subsubsection{The Value of Affection}

A value of love bestowed by the creator to humans so that the value of love has been embedded in each individual since he was born. The value of love contained in the novel Hatta: Aku Datang karena Sejarah by Sergius Sutanto, is as follows:

\subsubsection{Service}

Devotion is a good deed in the form of thoughts, opinions or energy. As an expression of loyalty, love, affection, respect, or a bond, and all that is done sincerely. Ke rumah inilah Hatta bawa orang-orang tercintanya, istri Rahmi binti Rachim, beserta tiga anak perempuan, Meutia, Gemala, dan si kecil Halida, setelah dia menyatakan resmi mundur dari jabatannya sebagai Wakil Presiden RI pada Desember 1956. Ya, aku kembali ke sini karena sebuah sejarah. (Halaman 16)

\section{Translate:}

It was to this house that Hatta brought his loved ones, Rahmi binti Rachim's wife, along with their three daughters, Meutia, Gemala, and little Halida, after he had officially announced his resignation from his position as Vice President of the Republic of Indonesia in December 1956. Yes, I returned here because of history. (Page 16)

The purpose of the quote above, the researcher analyzes that with Hatta officially resigning from his position as Vice President of the Republic of Indonesia, he has not forgotten his country. But still caring for his nation, that is by returning with his family because of a history of Indonesian independence that he could not leave just like that.

\subsubsection{Concern}

Concern is an attitude of our partisanship to involve ourselves in problems, circumstances or conditions that occur around us. Ingat, sudah berulang kali Inyik menasihati. Tidak baik menertawakan kesalahan apalagi kelemahan orang lain. (Halaman 51) 


\section{Translate:}

Remember, I've repeatedly advised. It's not good to laugh at mistakes let alone the weaknesses of others. (Page 51)

The purpose of the above quote, the researcher analyzes the contents of the quote explaining fellow human beings must care for one another or respect one another. Especially underestimating someone who is considered weak. Satu hal yang tak bisa dipungkiri, mereka memikirkan Hatta. Tiga bulan lebih Hatta mendekam di penjara. (Halaman 139)

\section{Translate:}

One thing that cannot be denied, they are thinking about Hatta. For more than three months Hatta was in prison. (Page 139)

The purpose of the quote above, the researchers analyzed that those around Hatta and even those out there were also thinking about the fate of Hatta who was languishing in prison. Whereas Hatta himself was following the rules as his service to the country.

Inti argumentasinya menegaskan bahwa pengajaranlah yang dapat mengantarkan rakyat ke arah kemajuan, bukan agama Islam atau Kristen. Untuk itu, katanya, diperlukan buku-buku yang bermanfaat dan bersifat mengajar, yang "mendorong orang pribumi berpikir dan memperhatikan". (Halaman 153)

\section{Translate:}

The essence of his argument is that teaching is what can lead people towards progress, not Islam or Christianity. For this reason, he said, books that were useful and of a teaching nature were needed, which "encouraged native people to think and pay attention". (Page 153)

The purpose of the above quote, researchers analyze if one of what we learn can add to our knowledge, and we can explore it as high as possible for a brighter future, and can share knowledge with others so that life is more meaningful. Then, the book is a storehouse of knowledge.

Hatta sudah menyerukan: Rakyat tidak bisa melulu dicekoki oleh agitasi dan jargon-jargon. Mereka butuh pembelajaran, butuh pendidikan yang akan mencerdaskan pemikiran guna meneropong masa depan. (Halaman 282)

\section{Translate:}

Hatta has called for: The people cannot always be force-fed by agitation and jargon. They need learning, they need education that will educate their minds to look into the future. (Page 282)

The purpose of the quote above, the researcher analyzes a service that holds fast so that people are not affected by things that mingle with distorted incitement.

\subsubsection{Kinship}

Kinship is a feeling that humans want to create to strengthen the relationship between the two, as well as per group so that love and brotherhood arise. Kau harapan kami semua, Hatta. Ingatlah ini terus kemana pun kau pergi. (Halaman 65)

\section{Translate:}

You're our hope, Hatta. Keep this in mind wherever you go. (Page 65)

The purpose of the quote, the researchers analyze if they all highly respect Hatta and support with what he did, because Hatta is a servant of this nation. Belum lama Hatta mengenal sahabatnya ini, namun seperti berpuluh-puluh tahun. Sebuah kedekatan telah tercipta semenjak mereka berdua dipecat dari keanggotaan Perhimpoenan Indonesia. Dalam banyak hal, sesungguhnya karakter mereka amat berbeda, bumi dan langit. Tapi entah kenapa, mereka merasa nyaman satu sama lain. Sjahrir memiliki potensi yang tinggi pada pertemanan, dan itu Hatta rasakan, pun teman-teman lainnya. (Halaman 224)

\section{Translate:}

Not long ago Hatta knew his best friend, but it seemed like decades. A closeness has been created since the two of them were fired from the membership of the Indonesian Association. In many ways, their real character is very different, earth and sky. But somehow, they feel comfortable with each other. Sjahrir has high potential for friendship, and that is Hatta's feeling, as well as other friends. (Page 224)

From this quote, the researcher analyzes that Hatta already considers his own best friend Sjahrir as his family.

\footnotetext{
"Situasi ekonomi yang tak menentu, membuat kami harus hidup sederhana, mungkin." Sjahrir tersenyum getir saat mengatakan beberapa sahabat silih berganti mengirimkan beras, ikan asin, dan segala keperluan lain karena tak adanya persediaan di rumah. "Rumah ini selalu terbuka lebar. Datanglah sesukamu. Saya akan membantu sebisa mungkin." (Halaman 244)
}

\section{Translate:}

"The uncertain economic situation, makes us have to live simply, maybe." Sjahrir smiled bitterly when he said that several friends took turns sending rice, salted fish, and all other necessities because there were no supplies at home. "This house is always wide open. Come as you wish. I will help as much as possible. "(Page 244)

From the quote above, the researcher analyzes an activity carried out as a family tradition that is created and helps one another as a group human.

\subsubsection{Mutual Help}

Mutual help is mutual help between humans. Selfless help and help without expecting anything in return. Hatta melihat jas yang dikenakannya. Memang sudah agak lusuh. Tak apalah aku memesannya satu dari penjahit ini. (Halaman 293) 


\section{Translate:}

Hatta saw the suit he was wearing. It's rather shabby. Never mind I ordered one of these tailors. (Page 293)

In the quotation above, the researcher analyzes that the tailor has given Hatta the trust, arguing that the people are worthy of trust, while Hatta does not mind if this is a help from the tailor.

\subsubsection{Loyalty}

Loyalty is one of the beliefs of self or joint in the emotional form in humans. Cinta Hatta tersimpan di hati dan memancar di mata. Seperti mata Rahmi yang sore ini berbinar bahagia. Sudah dua puluh lima tahun mereka bersama, mengarungi perjalanan panjang yang berkelok-kelok, jatuh bangun dalam senang dan duka. (Halaman 342)

\section{Translate:}

Hatta love is stored in the heart and radiates in the eyes. Like Rahmi eyes, this evening shining happily. They have been together for twenty-five years, wading a long, winding journey, ups and downs in joy and sorrow. (Page 342)

From the above quote, surely we all know what love is felt by every creature on earth. And loyalty is a beautiful thing but it is difficult to do with various obstacles that must be passed, it is faithfulness that is able to lead to eternal love, broad love in the affection of fellow believers. In the quote above, the researcher analyzes that if twenty-five years are not a short time, the tens of miles traveled in the faithful story we need to learn that the value of love is very beautiful and pleasant. Therefore they live it with sincerity.

\subsubsection{Value of Responsibility}

An act done by every individual based on one's obligations and heart. Namely attitudes that indicate that someone has a high caring nature. The value of responsibility contained in the novel

Hatta: Aku Datang karena Sejarah by Sergius Sutanto, that is the value of empathy. Empathy is an ability to imagine what other people might feel or think. Banyak kenangan di sini. Sekali lagi. Ini bukan sekadar alasan "perempuan". Walau dia sangat bersimpati pada Fatmawati yang hidupnya seperti digantung bak layang-layang putus. Cerai tidak, rujuk pun tak tampak. Sementara Soekarno sahabatnya makin asik dengan wanita lain. (Halaman 8)

\section{Translate:}

Many memories here. Once again. This is not just a "female" reason. Although he was very sympathetic to Fatmawati whose life was like being hung like a broken kite. Divorced not, even the reconciliation is not visible. While Sukarno, his best friend is getting more fun with other women. (Page 8)

The purpose of the quote above, the researcher analyzes that it is not only the place of residence that has memories, but there is another reason that makes a memory here, namely the figure of a woman named Fatmawati. Hatta could not bear to actually see the condition of Fatmawati whose status was now hung by Sukarno, divorced not even reconciled. Meanwhile, Sukarno was engrossed with other women out there without thinking about his relationship with Fatmawati. Hatta pandangi Arnold. Wajahnya muram. Bukan perkara yang mudah, memang. Hatta bisa merasakan kepedihannya andai harus terpisah dari pendidikan yang sedang berjalan. Karena aku pernah merasakannya. Memutuskan berhenti sekolah kemudian bekerja adalah saatsaat galau dan itu sangat tidak menyenangkan. (Halaman 100)

\section{Translate:}

Hatta looked at Arnold. His face is grim. Not an easy matter, indeed. Hatta could feel his pain if it had to be separated from the ongoing education. Because l've felt it. Deciding to quit school and then working is a time of confusion and it is very unpleasant. (Page 100)

The purpose of the quote above, the researcher analyzes if the two feel each other. So we need to realize that maybe God gave us the best way. Yang dipikirkan Hatta adalah nasib pendidikan di negeri ini. Kasihan jika generasi muda harus dicekoki ajaranajaran yang merupakan rekayasa kepentingan sekelompok orang. (Halaman 284)

\section{Translate:}

What Hatta thought was the fate of education in this country. Pity if the young generation must be fed with teachings that are fabricated by the interests of a group of people. (Page 284)

In the quote, the researcher analyzes that what Hatta is thinking is something that is very important for his people to be able to learn and gain useful knowledge about the future, the future fate of the nation, and the dream of this country.

"... sejarah dunia memberi petunjuk pula bahwa diktator yang bertanggung kepada kewibawaan orang seorang tidak lama umurnya. Sebab itu pula sistem yang dilahirkan Soekarno itu tidak akan lebih panjang umurnya dari Soekarno sendiri. Umur manusia terbatas. Apabila soekarno tidak ada lagi, maka sistemnya itu akan roboh dengan sendirinya seperti sebuah rumah dari kartu. (Halaman 285)

Translate:

"... world history also hints that a dictator who is responsible for the authority of a person is not old. Because of that, the system that was born by Sukarno would not last longer than Sukarno himself. Human life is limited. If Sukarno no longer exists, the system will automatically collapse like a house of cards. (Page 285)

In the quote above, the researcher analyzes that the analogy is indeed very real, that if human age is limited it does not even know man's final destiny. Therefore, it is necessary for a generation to replace it so that the earth will be maintained until later.

\subsubsection{Value of Life Harmony}

The value of harmony in life contained in the novel Hatta: Aku Datang karena Sejarah by Sergius Sutanto, are as follows:

\subsubsection{Tolerance}

Tolerance is an attitude of mutual respect between groups or between individuals in society or in other spheres. Tolerance can avoid discrimination, even though there are many different groups 
or groups in a community group. Dia menghargai semua air mata di rapat parlemen dan masyarakat luas, menghormati segala simpati yang dilayangkan setelah dirinya menyatakan resmi mundur pada 1 Desember 1956. (Halaman 19)

Translate:

He appreciated all tears at parliamentary meetings and the wider community, honoring all the sympathy that was waged after he declared his official resignation on December 1, 1956. (Page 19)

The purpose of the quote above, the researcher analyzes that Hatta has his own reasons for resigning from his position, because he did not want to be a circus spectator who was forced to cheer, after the stage, even though the stage did not please him. Although many invitations from various friends to join in business or invitation to other positions, Hatta still refused. Hatta menyela, "Kenapa orang Ambon? Katanya revolusi, tapi mengapa membunuh bangsa sendiri? Yang tidak bersalah mau dibunuh?" (Halaman 251)

\section{Translate:}

Hatta interrupted, "Why Ambonese? They say revolution, but why kill your own nation? The innocent want to be killed? "(Page 251)

By means of the quote above, the researcher analyzes that we must not discriminate between the differences that exist in our environment, even outside our environment. Mutual respect and mutual acceptance of differences in Indonesia with various ethnic groups that exist and together build mutual kinship so that this country remains united. Bagi Hatta, menjadi rakyat biasa adalah sebuah pilihan yang tepat. Tidak ada gunanya memangku jabatan bila suara terkunci dalam labirin kemelut yang tak berujung. (Halaman 279)

\section{Translate:}

For Hatta, being an ordinary person was the right choice. There is no point in taking office if the sound is locked in an endless maze of chaos. (Page 279)

The purpose of the quote above, the researcher analyzes that Hatta was not crazy in the throne, he devoted himself wholeheartedly because he wanted his people to be independent not because he was going to be crazy in his office.

\subsubsection{Cooperation}

Cooperation is an effort made by several people or groups to achieve a common goal. Cooperation is a form of interaction that is very important for human life, because humans are social beings who need each other. Cooperation can occur when the individuals concerned have the same interests and awareness to achieve common goals and interests. Anak-anak muda ini adalah harapan bangsa dan akan menjadi pemimpin rakyat di masa datang. Dari sekarang kita perlihatkan kepada mereka kewajiban itu. Kita bawa mereka berhubungan langsung dengan rakyat dan pemimpin-pemimpinnya rakyat. (Halaman 67)

\section{Translate:}

These young people are the hope of the nation and will be the people's leaders in the future. From now on we show them that obligation. We bring them in direct contact with the people and their leaders. (Page 67)

The purpose of the quote above, the researcher analyzes that Hatta wants a freedom or a change in this country, so that the corporeal work that only tortures the people in this country can be immediately destroyed.

\subsubsection{Democratic}

The democratic attitude in the deliberation itself is actually divided into three according to the process of deliberation, namely the democratic attitude when planning the deliberations, the democratic attitude when the deliberations take place, and the democratic attitude when the deliberations have gotten results. Mereka adalah pahlawan. Pahlawan yang tidak pernah ingin dikenal. (Halaman 223)

\section{Translate:}

They are heroes. A hero who never wants to be known. (Page 223)

The purpose of the quote above, the researcher analyzes that this attitude needs to be emulated because exhibition is not good as character. So we need to realize let the sincerity of the heart speak without showing off a position or fame. Koperasi adalah jalan keluar bagi kemiskinan dan kesengsaraan hidup. Kaum buruh dan petani miskin mempunyai keyakinan bahwa hanya dengan koperasi mereka dapat berbuat sesuatu untuk memperbaiki nasibnya. (Halaman 311)

\section{Translate:}

Cooperatives are a way out for poverty and misery. The poor workers and farmers have the belief that only with cooperatives can they do something to improve their lot. (Page 311)

The purpose of the quote above, obtained information that the cooperative is a tool or media that can help people from poverty. With the existence of cooperatives, the community is helped from all the existing crises.

\section{CONCLUSION}

Based on the results of research and discussion, it can be concluded that the social values in the novel Hatta: Aku Datang karena Sejarah by Sergius Sutanto has three social values, namely: the value of love, the value of responsibility, and the value of harmony in life. The most common element in social value is social value in the value of affection. This value of affection is found because there are values of dedication, caring, kinship, help, and loyalty in the novel Hatta: Aku Datang karena Sejarah. In the novel Hatta: Aku Datang karena Sejarah by Sergius Sutanto, the author also presents the life of Bung Hatta in his time. This certainly can provide the value of knowledge that is not yet known by the public about the life of the first vice president of the Republic of Indonesia. 


\section{REFERENCES}

[1] Aminuddin. (2015). Pengantar Apresiasi Karya Sastra. Bandung: Sinar Baru Algensindo.

[2] Andrew, K. (2018). Theoretical Justification for Social Value. Social Value in Construction, 60-68. doi:10.1201/9781315100807-4

[3] Gloriani, Y. (2013). Kajian Nilai-Nilai Sosial dan Budaya pada Kakawihan Kaulinan Barudak Lembur serta Implementasinya dalam Pembelajaran Bahasa dan Sastra Indonesia Berbasis Multikultural. Lokabasa, 4(2). doi:10.17509/jlb.v4i2.3147

[4] Hasanuddin, N. (2016). Nilai-Nilai Sosial dan Religi dalam Tradisi Megalitik di Sulawesi Selatan. Kapata Arkeologi, 12(2), 191. doi:10.24832/kapata.v12i2.313

[5] Hudhana, W. D. \& Sulaeman, A. (2019). Pengembangan Media Video Scribe dalam Peningkatan Kemampuan Menulis Cerpen Berbasis Karakter Siswa Kelas X SMA se-Kabupaten Tangerang. Pena: Jurnal Pendidikan Bahasa dan Sastra, 9(1), 31-46. doi:10.22437/pena.v9i1.6839

[6] Karto, Suhartono, Susetyo, Noermanzah, Maisarah, I. (2019). The Differences Ability in Writing Descriptive Texts by Using Chain Writing and Conventional Methods. International Journal of Scientific and Technology Research, 8(10).

[7] Martin, M. (2016). Nilai Sosial dalam Cerpen Koran Singgalang Edisi Januari-Februari Tahun 2015 Kajian Sosiologi Sastra. Menara IImu, 10(72), https://jurnal.umsb.ac.id/index.php/menarailmu/article/ view/29

[8] Noermanzah \& Friantary, H. (2019). Development of Competency-Based Poetry Learning Materials for Class X High Schools. International Journal of Recent Technology and Engineering, 8 (4).

[9] Noermanzah, N. (2017). Plot in a Collection of Short Stories "Sakinah Bersamamu" Works of Asma Nadia with Feminimism Analysis. Humanus, 16(1), 27. doi:10.24036/jh.v16i1.7015

[10] Noermanzah, Wardhana, D. E. C., Friantary, H., Arsyad, S. (2019). Joko Widodo's Rhetorical Structure in the Presidential Speeches for Addressing Educational Problems. International Journal of Scientific and Technology Research, 8(10).

[11] Nugroho, A. (2018). Nilai Sosial dan Moralitas dalam Naskah Drama Janji Senja Karya Taofan Nalisaputra. Silampari Bisa: Jurnal Penelitian Pendidikan Bahasa Indonesia, Daerah, dan Asing, 1(2), 28-42. doi:10.31540/silamparibisa.v1i2.153

[12] Nurgiyantoro, B. (2013). Teori Pengkajian Fiksi. Yogyakarta: Gadjah Mada University Press.

[13] Sulaeman, A. \& Goziyah. (2019). Metododologi Penelitian Bahasa dan Sastra. Jakarta: Edu Pustaka.

[14] Tool, M. R. (2019). Equational Justice and Social Value. Essays in Social Value Theory, 126-134. doi:10.4324/9781315494616-6

[15] Zubaedi. (2005). Pendidikan Berbasis Masyarakat. Yogyakarta: Pustaka Pelajar. 